\title{
Rekonstruksi Islamisasi Sains Sebagai Langkah Awal Islamisasi Ilmu: Pemikiran Syed Muhammad Naquib Al-Attas
}

\section{Dody Irawan}

IAIN Syaikh Abdurrahman Siddik Bangka Belitung, Indonesia dodayexcellent@gmail.com

\begin{abstract}
Muhammad Naquib al-Attas was the first figure who explicitly stated the project of Islamization of knowledge, when a conference held in Mecca. In the concept of religion there are at least several concepts that are contained, namely: faith (belief), Islam (obedience) and ihsan (integration between heart and mind in good deeds) and all of this, driven by science. Reconstruction of Al-Attas's thinking originated from his concern for the narrowing of meaning to Islamic scientific terms caused by attempts at westernization, mythology, inclusion of things that are magical and secularism. In line with its strategy of Islamization, al-Attas seems to use the approach of Islamization of science as a springboard to correct modern discipline and purify the sciences that have been contaminated by ideology of secularism. Knowledge in al-Attas' view is something that is devolved from God to enter into the spirit, then interpreted by the forces that exist in that spirit to the birth of knowledge and forms of symbols or logical proportions or metamatise.
\end{abstract}

Keywords; the Reconstruction of Islamization of Science, Science, Muhammad Naquib alAttas.

\begin{abstract}
Abstrak
Muhammad Naquib al-Attas merupakan figur pertama yang secara eksplisit menyatakan proyek Islamisasi ilmu, ketika diadakan konferensi di Mekkah. Dalam konsep agama setidaknya ada beberapa konsep yang terkandung yaitu: iman (keyakinan), Islam (kepatuhan) dan ihsan (keterpaduan antara hati dan pikiran dalam perbuatan yang baik) dan semua ini, digerakkan oleh ilmu. Rekonstruksi Pemikiran al-Attas berawal dari keprihatinannya terhadap penyempitan makna terhadap istilah-istilah ilmiah Islam yang disebabkan oleh upaya westernisasi, mitologisasi, pemasukan hal-hal yang maqis (gaib) dan sekularisme. Sejalan dengan strategi Islamisasinya, al-Attas nampaknya menggunakan pendekatan islamisasi ilmu sebagai batu loncatan untuk mengoreksi disiplin modern dan memurnikan ilmu-ilmu yang telah terkontaminasi dalam paham-paham sekularisme. Pengetahuan dalam pandangan al-Attas merupkan suatu yang dilimpahkan dari tuhan hingga masuk dalam ruh, kemudian ditafsirkan oleh kekuatan-kekuatan yang ada dalam ruh tersebut hingga lahir pengetahuan dan bentuk simbol-simbol atau proporsi-proporsi logis atau matematis.
\end{abstract}

Kata kunci; Rekonstruksi Islamisasi Sains, Ilmu, Muhammad Naquib al-Attas.

Received: 10-06-2019; accepted: 10-07-2019; published: 18-07-2019

Citation: Dody Irawan, 'Rekonstruksi Islamisasi Sains Sebagai Langkah Awal Islamisasi Ilmu: Pemikiran Syed Muhammad Naquib Al-Attas', Mawa'izh, vol. 10, no.1 (2019), pp. 1-17. 


\section{A. Pendahuluan}

Peradaban modern telah memunculkan problem-problem kemanusiaan dan lingkungan yang sangat serius. Krisis peradaban itu telah mengantarkan manusia dalam ancaman kepunahan, kerusakan lingkungan, disharmoni kehidupan, dan sebagainya. Sejalan dengan pilar peradaban modern yang merupakan ilmu pengetahuan, maka sejumlah pemikir merasa sangat berkepentingan untuk menelaah kembali ilmu pengetahuan secara kritis.

Salah satu tokoh kunci dalam diskursus Islamisasi sains adalah Syed Muhammad Naquib Al-Attas. Dialah orang pertama yang secara eksplisit menyatakan dan "meresmikan" proyek Islamisasi ilmu ketika diadakan Konferensi Pendidikan Islam Internasional di Mekkah pada tahun 1977. Ide ini kemudian disempurnakan sendiri lewat beberapa buku yang ditulis dan diterbitkan tahun 1978. Menurutnya Islamisasi bukanlah sekadar mempertemukan atau menyandingkan ilmu umum dan ilmu keislaman, melainkan lebih merupakan rekonstruksi ontologis dan epistemologis ilmu umum yang tidak sesuai dengan nilai-nilai Islam agar sesuai dengan nilai-nilai Islam. Sebab, dari sisi inilah lahir sebuah disiplin ilmu. ${ }^{1}$

Tanpa bermaksud untuk mengenang romantisme sejarah, Islam pernah mengalami masa keemasan peradaban, dengan tidak mengesampingkan faktor-faktor yang lain, juga disebabkan banyaknya karya-karya filsafat Yunani yang dikaji oleh para pemikir Muslim untuk kemudian diasimilasikan dan dirumuskan menjadi sebuah pemikiran filsafat Islam.

Gagasan Al-Attas ini ternyata mendapat sambutan luar biasa dari para intelektual Muslim dunia. Oleh karena itu, pada tahun yang sama diadakan konferensi I di Swiss, disusun Konferensi II tahun1983 di Islamabad, Pakistan; konferensi III tahun 1984 di Kuala Lumpur, Malaysia; konferensi IV tahun 1987 di Khortum, Sudan. Kemudian di Amerika, gagasan Islamisasi sains Naquib disambut masyarakat Islam yang dipelopori Ismail Raji Al-Faruqi (1921-1986 M) dengan mendirikan sebuah

\footnotetext{
${ }^{1}$ A. Khodri Soleh, Filsafat Islam Dari Klasik Hingga Kontemporer (Jakarta: Ar Ruzz Media, 2013), p. 303.
} 
perguruan tinggi, The International Instute of Islamic Thought (IIIT), di Washington DC, Tahun $1982 .^{2}$

Pada masa inilah Islamisasi ilmu pengetahuan mendorong berkembangnya ilmu pengetahuan dalam dunia Islam. Pada saat yang sama justru bangsa-bangsa Barat mengalami kemunduran peradaban dikarenakan sikap ortodoksi mereka terhadap dogma-dogma agama ciptaan mereka sendiri. Ketika kejayaan Islam runtuh, banyak literature ilmu pengetahuan Islam diadobsi atau dirampas oleh bangsa Eropa, sehingga Barat mengalami kemajuan yang pesat dalam ilmu pengetahuan. Melihat stagnasi pemikiran ilmuwan Muslim dalam pengembangan ilmu pengetahuan saat ini. Tentunya menjadi masalah urgen yang harus segera diselesaikan demi menumbuhkan progesifitas pengembangan ilmu pengetahuan yang menjadi masalah dalam dunia pendidikan Islam.

Sebagaimana diakui oleh para pemikir pendidikan Islam, bahwa degradasi pemikiran Islam disinyalir akibat dari kurangnya landasan epistemologi Islam dalam dunia pendidikan Islam itu sendiri. Terlebih lagi umat Islam selama ini "dininabobokkan" oleh sikap fatalistik yang diwariskan secara turun temurun. Sikap yang sebenarnya bertentangan dengan semangat al-Qur'an ini harus dibuang jauh-jauh untuk mewujudkan konsep insan kamil seperti yang dicontohkan dalam al-Qur'an dan Sunah Nabi. Sekuralisme sebagaimana yang ditulis tinta sejarah mulai muncul ketika Eropa (Barat) mengalami zaman renaissance.

Sekuralisme sendiri adalah konsekuensi paradigmatis yang berakar dari landasan epistemologi ilmu pengetahuan yang dibangun oleh para ilmuwan Barat. Para ilmuwan Barat secara frontal menolak campur tangan agama dalam masalah ilmu pengetahuan. Sebenarnya penolakan ini lebih disebabkan karena adanya pertentangan dari agama Kristen yang dianut oleh mayoritas kaum akademis dunia Barat yang tidak selaras dan tidak mampu berjalan beriringan dengan perkembangan ilmu pengetahuan. Dogma-dogma Kristiani disinyalir tidak sesuai dengan kebenaran ilmiah dari ilmu pengetahuan. Di dunia Islam sendiri, sekuralisme sampai saat ini masih menjadi perdebatan yang sengit dari berbagai kalangan pemikir Islam.

2 Jamil Barzinji, Sejarah Islamisasi Ilmu Pengetahuan dalam salam, ed2 \& 3 (Malang: Pps UMM, 1998), p. 59. 
Para pemikir Islam kontemporer mencoba menjawab tantangan sekularisme yang terjadi di Barat dengan konsep "islamisasi ilmu pengetahuan”. Terlepas dari prokontra terhadap konsep itu sendiri, sebab kemunculan islamisasi ilmu pengetahuan tidak bisa dilepaskan dari ketimpangan-ketimpangan yang merupakan akibat langsung dari keterpisahan sains dan agama. Tokoh-tokoh pendukung islamisasi ilmu pengetahuan antara lain Naquib Al-Attas, Ismail Raji al-Faruqi, Hussein Nasr, dan Ziauddin Sardar.

Pada kesempatan kali ini penulis ingin mengarahkan konsentrasi kajian ini terhadap salah satu tokoh dari sekian banyak tokoh "islamisasi ilmu pengetahuan" yaitu Syed Naquib Al-Attas. Dikarenakan banyak hal yang menarik untuk dikaji dari pemikiran-pemikirannya. Disamping itu Syed Naquib al-Attas juga memberikan sumbangsih yang tidak bisa dinafikan dalam dunia pendidikan Islam baik secara konseptual maupun praktiknya. Naquib secara sistematis merumuskan strategi Islamisasi ilmu dalam bentuk kurikulum pendidikan untuk umat Islam.

\section{B. Sketsa Biografi Syed Muhammad Naquib Al-Attas}

Syed Muhammad Naquib Al-Attas lahir di Bogor pada tanggal 5 September 1931 M. Silsilah keluarga beliau dapat diidentifikasi melalui silsilah Sayyid dalam keluarganya sampai kepada Imam Hussein, yaitu cucu Nabi besar Muhammad Saw. dari keturunan putri Nabi, yaitu Fatimah. ${ }^{3}$ Syarifah Raquan ibunda al-Attas merupakan keturunan ningrat sunda yang baerasal dari wilayah Bogor, Jawa Barat. Sedangkan Syed Muhammad al-Aydarus merupakan salah satu leluhur dari pihak ibunya yang menjadi wali dan ulama. ${ }^{4}$ Syekh Abdullah ibnu Muhsin ibnu Muhammad al-Attas kakek dari pihak bapaknya merupakan seorang wali yang berpengaruh di dataran Indonesia hingga ke negeri Arab. 5

Sebagai neneknya, Ruqaiyah Hanum berasal dari Turki yang masih keturunan aristocrat menikah dengan Ungku Abdul Majid, Ruqaiyah Hanum, adalah wanita Turki berdarah aristocrat yang menikah dengan Ungku Abdul Majid yang merupakan saudara

3 Silsilah resmi keluargaAl-Attas yang terdapat dalam koleksi pribadinya menunjukkan bahwa dia adalah keturunan ke-37 dari Nabi Muhammad Saw

4 Wan Mohd Nor Wan Daud, Filsafat dan Praktek Pendidikan Islam Syed M. Naquib al-Attas (Bandung: Mizan, 2003), p. 45.

5 Ibid, p. 44. 
dari Sultan Abu Bakar Johor yang wafat pada tahun 1895. Ia adalah pasangan Khadijah saudari Hanum yang menjadi Ratu Johor ketika itu. Hanum menikah dengan Syed Abdullah al-Attas setelah ditinggal wafat oleh Majid yang meninggalkan dua orang putra dan dikaruniai seorang putra lagi bernama Syed Ali al-Attas yang merupakan ayah dari Muhammad Naquib. ${ }^{6}$

Syed Muhammad Naquib al-Attas memiliki dua saudara kandung bernama Syed Hussein, putra pertama yang merupakan seorang ahli sosiologi dan menjadi wakil rektor Universitas di Malaysia (UM), adik bungsunya, Syed Zaid merupakan insinyur kimia dan sebagai dosen institute Teknologi MARA. Pendidikan Naquib sangat dipengaruhi oleh latar belakang keluarganya. Ia memperoleh pendidikan keislaman dari keluarga di Bogor, dan pendidikan dasar bahasa dan sastra serta budaya Melayu dari keluarga di Johor. ${ }^{7}$ Ia dikirim ke Sekolah Dasar NgeeHeng Johor pada tahun 1936 sampai tahun 1941 di usianya yang masih lima tahun dan tinggal bersama paman dan bibinya Ahmad dan Azizah yang merupakan anak dari Ruqoyah bersama suami pertamanya. $^{8}$

Naquib melanjutkan pendidikan di Madrasah urwatul al-Wustsqah di Jawa, tepatnya di Sukabumi yang merupakan lembaga pendidikan dengan bahasa pengantar bahasa Arab di masa pendudukan Jepang. Ia melanjutkan pendidikannya di Johor tahun 1946 pasca perang dunia ke-II di Bukit Zahrah Scholl, dan pada tahun 1946 sampai 1951 ia melanjutkan ke Engglish College. Ia tinggal bersama Ungku Azis ibnu Ungku Abdul Majid pamannya yang memiliki sebuah perpustakaan yang sangat bagus bermanuskrip Melayu terutama mengenai sastra dan sejarahnya. ${ }^{9}$

Pada tahun 1951 ia menamatkan sekolah Menengahnya, Naquib mendaftarkan diri pada resimen Melayu sebagai kadet guna mengikuti pendidikan meliter di Eton Hall untuk pertama kalinya, Chaster, Wales, dan selanjutnya di Royal Military Academy, Sandurst, Inggris pada tahun 1952 sampai 1955. Ia banyak mempelajari pemahaman semangat gaya hidup masyarakat Inggris. Setelah mendalami pendidikan militer, Naquib berkunjung ke tempat terkenal dengan tradisi seni, gaya bangunan dan intelektual keislaman. Ia sempat berkenalan dengan pejuang perebut kemerdekaan

\footnotetext{
${ }^{6}$ Ibid, p. 46.

7 Ibid.

${ }^{8}$ Ibid.

${ }^{9}$ Ibid, p. 50.
} 
Maroko dari penjajah Spanyol dan Prancis, hal ini memberikan pengalaman perkenalan pertama kalinya dengan pandangan Metafisika tasawuf. Pengalaman-pengalaman Syed ini, tentu memberikan kesan yang sangat mendalam bagi perjalanan hidupnya. ${ }^{10}$

Tidak lama, setelah menamatkan pendidikan meliternya dari Sandhurst, ia menempuh Program Sarjana di UM (Universitas Malaya). Setelah merampungkan Strata satu, terhitung sejak tahun 1960 ia disokong oleh Canada Council Fellowship dengan mendapatkan beasiswa selama tiga tuhun untuk belajar di Universitas McGill, Montreal, Institute of Islamic Studies yang didirikan Wilfred Cantwell Smith. Naquib mendapat gelar Master pada Universitas McGill pada tahun 1962 setelah menyelesaikan tesisnya yang berjudul Raniri and the Wujudiyyah of 17th Century Acheh, dengan predikat coumloude Hingga memperoleh gelar MA.

Setahun setelah mendapatkan gelar, ia didukung oleh beberapa sarjana dan tokoh-tokoh orientalis terkenal untuk pindah ke School of Orientalis and African Studies (SOAS) meneruskan pendidikan doktornya di Universitas London. Pada tahun 1965 Naquib memperoleh gelar Ph.D. dibawah bimbingan Profesor Arberry dan Dr. Martin Lings, setelah memperjuangkan desertasi doktornya dengan judul The Mysticism of Hamzah Fanshuri, dengan predikat sangat memuaskan.

Al-Attas telah menulis 26 buku dan monograf, baik dalam bahasa inggris maupun melayu dan banyak telah diterjemahkan ke dalam bahasa Urdu, Malayam, Indonesia, Prancis, Jerman, Rusia, Bosnia, Jepang, India, Korea, dan Albania Disamping karya yang berbentuk buku dan monograf, Naquib telah menyampaikan kurang lebih empat ratus makalah ilmiahnya di Negara-negara Eropa, Timur Tengah, Jepang, Amerika, dan berbagai Negara Islam lainnya. Selain itu, Naquib juga aktif menulis artikel-artikel dalam jurnal-jurnal international. Jumlah artikel ini tidak kurang dari 27 artikel dalam berbagai jurnal international. ${ }^{11}$

\section{Konsep Pemikiran Syed Muhammad Naquib al-Atas dalam Pandangan Islamisasi Ilmu Pengetahuan Modernisme}

Paradigma pemikiran Al-Attas bila dikaji secara historis merupakan sebuah pemikiran yang berawal dari dunia metafisis ke dunia kosmologis dan bermuara pada

10 Ibid.

11 Ibid, p. 57. 
dunia psikologis. Pemikiran al-Attas berawal dari keprihatinannya terhadap penyempitan makna terhadap istilah-istialh ilmiah Islam yang disebabkan oleh upaya westerniasi, mitologisasi, pemasukan hal-hal yang magis (ghaib) dan sekularisasi. ${ }^{12} \mathrm{Al}$ Attas memperkenalkan dan megemukakan proses de-westernisasi dan Islamisasi ilmu sebagai langkah awal membangun paradigma pemikiran Islam kontemporer.

\section{De-westernisasi dan Islamisasi Ilmu}

Istilah de-westernisasi merupakan suatu proses pembersihan dari pola gaya hidup barat, jika westernisasi dipahami sebagai pengadopsian atau pembaratan, pengambilan gaya hidup barat, maka de-westernisasi dapat dipahami sebagai upaya proses pelepasan dari gaya hiduo barat, atau dengan kata lain memurnikan sesuatu dari pengaruh barat dengan dukungan islamisasi ilmu. Menurut Naquib, Islamisasi merupakan proses pembebasan manusia dari mitodologis, tradisi magis, animisme, nasionalis kultural dan sekularisme. ${ }^{13}$ Singkatnya, bahwa batasan dewestrenanisasi merupakan proses mengenal, memisahkan dan mengasingkan unsurunsur sekuler yang terdiri dari substansi, roh, watak, dan kepribadian kebudayaan serta peradaban Barat dari tubuh pengetahuan yang akan merubah bentuk, nilai-nilai dan tafsiran konseptual dari isi pengetahuan seperti yang disajikan pada masa sekarang.

Islamisasi dapat diartikan sebagai identitas dan karakter Islam untuk menjadi pandangan hidup (worldview), di dalamnya terdapat pandangan integral terhadap konsep ilmu (epistemology) dan konsep Tuhan (theology). Lebih dari itu, Islam merupakan agama yang memiliki pandangan hidup fundamental terhadap Tuhan, alam semesta, manusia, kehidupan. Oleh karena itu, Islam disebut sebagai agama dan peradaban sekaligus. ${ }^{14}$

Secara historis, gagasan atau ide islamisasi ilmu pengetahuan muncul ke permukaan pada saat diselenggarakan konferensi dunia yang pertama kalinya pada tahun 1977 tentang pendidikan Islam di Makkah. Konferensi ini diprakarsai oleh King Abdul Aziz University dan berhasil mengupas seratus lima puluh makalah yang ditulis

12 Samsul Nizar, Filsafat Pendidikan Islam Pendekatan Historis, teoritis dan Praktis, (Jakarta: Ciputat Press, 2002), p. 124.

13 Syed M. Naquib al-Attas, Islam dan Sekularisme, (Bandung: Pustaka, 1981), p. 202.

${ }^{14}$ Saiful Muzani, Pandangan Dunia, hlm 84. Daftar Karya Naquib Secara Lengkap lihat bagian box buku referensi ini, p. 85; Naquib al-Attas, Islam dan Filsafat Sains, terjemah Zainal Abidin (Bandung: Mizan 1995), p. 8. 
oleh sarjana-sarjana dari empat puluh negara, untuk merumuskan rekomendasi bagi pembenahan dan penyempurnaan sistem pendidikan Islam yang diselenggarakan oleh umat Islam di seluruh dunia.

Islamisasi merpakan istilah yang membawa sesuatu ke dalam Islam atau membuatnya dan menjadikannya Islam. Istilah ini bukan berarti bahwa Islam itu tidak bersifat umum (universal), melainkan lebih berarti bahwa di luar Islam masih banyak berbagai macam hal yang jauh dari nilai-nilai keislaman itu sendiri. Justru istilah Islamisasi merupakan sebuah gambaran universal sebagai langkah atau suatu usaha untuk memahamkan segala sesuatunya dengan kerangka Islam (Islamic framework). Oleh karena itu, pemahaman akan sesuatu yang jauh dari nilai-nilai Islam tersebut dibutuhkan adanya upaya yang disebut sebagai Islamisasi. ${ }^{15}$

Bagi Naquib, definisi dari Islamisasi ilmu diperoleh dari idenya terhadap Islamisasi sacara umum. Yaitu sebuah upaya pembebasan manusia dari tradisi mitologis (mythology), magis (magical), nasional-kultural (national cultural tradition), animisme (animism), dan paham sekuler (secularism). ${ }^{16}$ Ia juga memaknai Islamisasi sebagai suatu proses hijrahnya manusia dari tradisi-tradisi tersebut di atas, meskipun manusia mempunyai komponen jasmani dan rohani sekaligus, namun pembebasan itu lebih menunjuk pada rohaninya, sebab manusia yang demikianlah disebut sebagai manusia sejati yang semua tindakannya dilakukan dengan sadar penuh nilai dan makna. Naquib mensifatkan sebagai proses pembebasan, karena proses tersebut melibatkan pembebasan roh manusia yang mempunyai pengaruh atas dirinya secara jasmani. Proses ini akan berdapak positif menimbulkan keharmonian dan kedamaian dalam diri sesuai dengan fitrah manusia itu sendiri (original nature). Maka dapat ditarik kesimpulan, bahwa Islamisasi ilmu merupakan upaya pembebasan ilmu dari penafsiran-penafsiran yang disandarkan pada ideologi sekuler dan dari makna-makna ungkapan manusia-manusia sekuler.

Al-Attas menambahkan, setidaknya terdapat dua makna Islamisasi, yaitu suatu pikiran dari pengaruh ekternal dan pikiran dari dorongan internal. Pertama, upaya pembebasan pikiran dari pengaruh magis (magical), mitologis (mythology), animisme (animism), nasional-kultural (national cultural tradition), dan paham sekuler 
Mawaizh

Jurnal Dakwah dan Pengembangan Sosial Kemanusiaan

Vol. 10, no. 1 (2019), pp. 1-17.

DOI: https://doi.org/10.32923/maw.v10i1.781

(secularism). Sedangkan yang kedua upaya pembebasan jiwa manusia dari sikap tunduk kepada keperluan jasmaninya yang condong mendzalimi dirinya sendiri, sebab sifat tersebut lebih condong untuk lalai terhadap fitrahnya sehingga mengganggu keharmonian dan kedamaian dalam dirinya yang pada gilirannya menjadi jahil tentang tujuan asalnya yaitu untuk beribdah. Jadi Islamisasi bukanlah satu proses evolusi ( $a$ process of evolution) tetapi juga merupakan suatu proses pengembalian kepada fitrah manusia (original nature).

\section{Metafisika dan Epistemologi}

Pemikiran metafisika Naquib berawal dari paham teologis. Dalam tradisi Islam di kenal istilah tasawuf. Ia memberikan batasan yang jelas mengenai berbagai tingkatan orang yang melakukan olah spiritual tasawuf atau salik dalam dunia sufi. Ada tiga tingkatan yang merupakan sebuah peringkat yang bersifat hirarkis atau bertingkattingkat. Pertama: disebut mubtadi,' atau tingkatan awal, dalam tingktan ini si salik hanya terbatas melakukan amalan-amalan yang yang berkisar pada masalah moral dan adab saja. Kedua: disebut mutawasith, dalam tingkatan yang kedua ini si salik sudah mulai melakukan wirid, doa dan zikir mengenai kualitas, kuantitas, yang frekuensinya ditentukan oleh sang mursyid dan harus dilakukan secara terus-menerus (kontinu). Ketiga: disebut muntahiy, pada tingkatan ini si salik memasuki dunia metafisika dan filsafat yang prosesnya diwajibkan memiliki pengetahuan yang mendalam tentang ilmu kebijaksanaan-ketuhanan (al hikmah al ilahiyah), ilmu syari'ah atau ilmu naqliyyah (al'ulum al syri'ah), dan ilmu rasional (al 'ulum al aqliyyah.) ${ }^{17}$

Dengan ketiga jenis pengetahuan ini, maka tasawuf yang dikemukakan Naquib al-Attas lebih dikenal dengan sebutan tasawuf falsafiy. Sedangkan tasawuf yang membatasi dirinya pada tingkatan pertama dan kedua dikenal dengan istilah tasawuf akhlaqiy. Al-Attas berpendapat bahwa pencapaian tingkat tertinggi dalam tasawuf mengandung pencapaian sebuah pengetahuan atau ma'rifah, maka seseorang sudah dikatakan mencapai tingkat muntahiy atau peringkat teratas dalam dunia tasawuf jika telah mencapai tingkat tetinggi dalam bidang pengetahuan. ${ }^{18}$

17 Abdul Rahmat Haji Abdullah, Pemikiran Islam di Malaysia, Seajarah dan Aliran, (Jakarta: Gema Insani Press, 1997), p. 65.

18 Wan Daud, Filsafat dan Praktek Pendidikan Islam, p. 56 
Untuk memahami inti epistemologi Barat perlu dikemukakan pandangan al-Attas tentang asumsi epistemologi modern. Al-Attas mengatakan bahwa inti asumsi-asumsi episteotentik; bahwa ilmu yang berhubungan dan bersangkut paut dengan fenomena; bahwa sains, termasuk pernyataan pernyataan dasar umum sains dan filsafat yang diturunkan darinya adalah khas bagi zaman tertentu; bahwa yang diterima hanyalah teori-teori yang direduksi kepada unsur-unsur indrawi, melibatkan gagasan yang melampai jangkauan pengalaman empiris. ${ }^{19}$

Epistemologi sains modern berpijak pada landasan pemisahan agama dalam ilmu pengetahuan. Sains modern tumbuh dan berkembang dari tradisi filsafat yang menafikan kekuasaan dan keberadaan Tuhan dalam pengembangan ilmu pengetahuan. Landasan epistemologi sains modern bersandar pada metode rasionalis-empiris dan menyangkal peran intuisi serta menolak wahyu agama sebagai sumber ilmu yang benar. ${ }^{20}$

Dalam tradisi ilmiah modern inilah agama dikatakan hanya menjadi belenggu dalam proses dinamika pengembangan ilmu, karena agama tidak mampu menjawab tantangan zaman yang semakin hari semakin bertumpu pada teknologi. Hegemoni pengetahuan barat yang begitu kuat mengakar diseluruh penjuru dunia, tanpa disadari telah diimani oleh sebagian besar umat Muslim. Umat Muslim menerimanya tanpa adanya upaya kritis untuk lebih dalam tentang bagaimana epistemologi yang dikandung oleh sains modern sekarang ini. Adanya anggapan bahwa sains modern adalah satusatunya cabang ilmu yang otoritatifnya melemahkan pandangan Islam mengenai ilmu. Padahal, menurut penulis, jika agama dipandang sebagai sebuah ilmu, maka agama ini merupakan suatu pengetahuan yang bisa berkembang tanpa batasan-batasan tertentu. Akan tetapi, jika agama hanya dipandang sebagai ritual, maka agama hanya sebatas ritual syariat yang dijalankan penganutnya saja. Pemahaman inilah yang perlu disebarluaskan kepada seluruh kalangan umat universal.

Al-Attas menolak preposisi sains modern sebagai sumber pencapaian kebenaran yang paling otoritatif dalam kaitannya dengan epistemologis, karena banyak kebenaran agama yang tak dapat dicapai oleh sains. Pada tingkat dan pemaknaan seperti ini, sains modern telah terlepas jauh dari kebenaran. Kebenaran dalam Islam sendiri merupakan

19 Al-Attas, Islam dan Filsafat Sains, p. 34.

${ }^{20}$ Saleh, Filsafat Islam, p. 313. 
titik kulminasi seluruh aktifitas intelektual dan intuitif yang mampu dicapai manusia dengan segala potensi yang telah diberikan Tuhan.

Dalam paradigma pemikiran Islam, pencapaian ilmu pengetahuan tidak berhenti pada terminal kesesuaian antara realitas rasio dengan realitas inderawi saja, tapi lebih dari itu merupakan kesesuaian dan keserasian antara realitas intelektual-intuitif dengan realitas ontologis. Epistemologi Islam tidak berangkat dari keraguan (sebagaimana sains modern barat dikembangkan dengan berlandaskan kepadanya), melainkan berangkat dari keyakinan akan adanya kebenaran itu sendiri. ${ }^{21}$

Kebenaran yang secara inheren telah terkandung dalam al-Qur'an sebagai petunjuk Tuhan. Kebenaran yang secara esensial tersembunyi dibalik alam semesta, baik yang berkaitan dengan gejala-gejala, proses maupun peristiwa-peristiwa alam dan kemanusiaan. Bagi al-Attas sendiri, dalam proses pembalikan kesadaran epistemologis ini, program islamisasi menjadi satu bagian kecil dari upaya besar pemecahan masalah epistemologi ilmu pengetahuan.

Sejalan dengan strategi Islamisasinya, Al-Attas tidak mecampakkan begitu saja inti asumsi epistemologi barat. Al-Attas nampaknya menggunakan pendekatan tersebut sebagai batu loncatan untuk mengoreksi disiplin modern dan memurnikan ilmu-ilmu Islam yang telah tercelup dalam paham-paham sekularisme.

Dengan landasan filsafat, maka metode-metode utama yang dikembangkan tidak luput dari tiga metode yaitu: pertama, nasionalisme filosofis yang cenderung pada indrawi. Kedua, rasionalisme sekuler yang cenderung lebih bersandar pada pengalaman inderawi dan menyangkal otoritas serta menolak bahwa wahyu agama merupakan sebuah sumber ilmu. Ketiga, empirisme filosofis atau empirisme logis yang menyandarkan seluruh ilmu pada fakta-fakta yang dapat diamati bangunan logika dan analisis bahasa. ${ }^{22}$

\section{Sumber dan Metode Pengetahuan}

Sumber dan metode ilmu Naquib mengatakan bahwa ilmu datang dari tuhan dan diperolah melalui sejumlah saluran indera yang sehat, laporan atau informasi yang disandarkan pada otoritas akal sehat dan intuisi. Berdasarkan hal ini, menurut Muzani, apa yang disebut sebagai pengetahuan dalam pandangan Naquib al-Attas, adalah

21 Nizar, Filsafat Pendidikan Islam, p. 132.

22 Al-Attas, Islam dan Filsafat Sains, p. 28. 
sesuatu yang melimpah dari tuhan hingga masuk dalam ruh kemudian ditafsirkan oleh kekuatan-kekuatan yang ada dalam ruh tersebut hingga lahir pengetahuan dalam bentuk simbol-simbol atau proposisi-proposisi logis atau metamatis. ${ }^{23}$

Dengan penyebutan istilah "indra yang sehat" dimaksudkan sebagai indra lahiriyah yang meliputi perasa tubuh, pencium, perasa lidah, penglihatan, dan pendengaran. Terkait dengan indra yang bersifat lahiriyah di atas indra batin yang secara batiniyah mempersepsi citra-citra indrawi dan maknanya, menyerap atau mengkonsepsi gagasan-gagasan, menyimpan hasil penyerapan dan pengingatan kembali atau rememory.

Al-Attas juga menegaskan indra batin yang terdiri dari lima perangkat adalah: Pertama, indera bersama (al-hissy al-musytarak), yaitu indera batin yang berhubungan dan menangkap segala yang ditangkap kelima indera lahir, kedua, repsentasi (alquwwat al-khayal) yaitu indera batin yang menyimpan hasil abstrak indera bersama, ketiga, estimasi (al-quwwat al-wahmiyah) yaitu indera batin yang mampu membentuk opini tetapi hanya didasarkan pada penafsiran instinktif. Keempat, Rekoleksi (alquwwat al-hafidhah al-dzakirah wa al-mutadzakkirah) yaitu indera batin yang menyimpan hal-hal abstrak yang telah diterima oleh estimasi, dan kelima, imajinasi (alquwwat al-mutakhayyilah, al mufakkirah) yaitu indera batin yang menjadi sarana penghubung antara jiwa binatang. ${ }^{24}$

Sebagai upaya rektualisasi pemikiran filsafat Islam klasik, maka pemikiran AlAttas dalam masalah ini telah mampu mengelaborasikan dengan pandangan metafisika. Dalam pandangannya antara metafisika dan epistemologi merupakan sebuah sistem yang integral. Sebab metafisika merupakan landasan utama bagi epistemologi. Sementara asumsi dasar yang menjadi mainstream al-Attas adalah keyakinan adanya integritas yang kuat antara dimensi, metafisika, kosmologis dan psikologis.

Akal tidak bisa dipisahkan dengan intuisi pada manusia. Peran intregitas akal dan intuisi dalam epistimologi Islam merupakan sebuah keniscayaan. Sebab diantara dua unsur di atas walaupun mempunyai karakteristik yang berbeda, yaitu bila akal itu mengarah kepada hal-hal intelligible yang dapat diupayakan (suatu yang dapat dicerna

${ }^{23}$ Syaiful Muzani, 'Pandangan Dunia dan gagasan Islamisasi SM. Naquib al-Attas', al-Hikmah, no. 3, (1991), p. 94.

${ }^{24}$ Nizar, Filsafat Pendidikan Islam, p. 137. 
akal), sedangkan intuisi mengarah pada hal-hal sensible yang dianugrahkan (dapat di cerna oleh akal), akan tetapi merupakan unsur yang sama. Maksudnya bila akal merupakan salah satu sarana aktivitas jiwa yang tentunya berkaitan dengan ruh dan qalbu, maka intuisi juga merupakan hal yang sama.

\section{Epistimologis Pencapaian Makna}

Istilah "makna" dipahami Naquib sebagai pengenalan masing-masing tempat yang tepat dari suatu sistem yang terjadi. Ketika hubungan antara sesuatu itu dengan lainnya dengan sistem menjadi jelas dan mudah dipahami. Makna adalah suatu bentuk citra aqliah (intelligible) yang ditunjukkkan oleh suatu kata, ungkapan, atau lambang.

Selanjutnya berhubungan dengan pencapaian suatu makna, unsur manusia adalah elemen yang menjadi titik sentral di dalamnya. Karena itu manusia di definisikan sebagai hewan rasio (hayawan al nathiq). Dan rasio adalah diambil dari kata nathiq, yang mengacu pada sebuah pengetahuan bawaan yang mampu memahami sebuah makna. Eksistensi manusia mempunyai tingkat tingkat berbeda tergantung pada jangkauan operasi indra lahir dan batin, tingkat eksistensi tersebut adalah:

Pertama, eksistensi yang real atau nyata, yang merupakan eksistensi pada tingkatan objektif seperti dunia lahir. Kedua, eksistensi yang dapat di indera dan terbatas pada komponenen-komponen indera serta pengalaman indrawi, termasuk mimpi, penglihatan batin dan ilusi merupakan pengalaman inderawi dalam imajinasi ketika objek-objek itu tidak ada dalam persepsi manusia. Ketiga, eksistensi intelektual yang terdiri atas konsep-konsep abstrak dalam pikiran manusia. Keempat, eksistensi analog, yang dibentuk oleh hal-hal yang tidak wujud pada tingkat-tingkat yang telah di sebut diatas, akan tetapi wujudnya seperti hal lain yang menyerupai hal-hal tertentu.

Selain dari tingkatan yang telah disebutkan diatas, Al-Attas juga mengakui adanya tingkatan yang lain selain tingkat eksistensi pada tingkat kebenaran yang rasional yakni tingkatan suprarasional atau transcendental yang dialami oleh para nabi, wali Allah, dan orang-orang bijak yang amat dalam ilmunya, sehingga tingkatan ini disebut tingkatan eksistensi suci.

\section{Moralitas dan Pengetahuan}

Moralitas dan pendidikan merupakan lanjutan dari pemikiran manusia tantang konsep agamanya. Dalam Islam dikenal ada istilah din (agama), maka dalam hal ini yang 
menjadi kajian pertama adalah konsep din itu sendiri sebelum membahas hal-hal yang lainnya. menurut Al-Attas salah satu terminologi yang menjadi sorotan utama adalah yang berkaitan dengan moralitas dan pendidikan yang menjadi istilah dalam agama. ${ }^{25}$

Dalam konsep agama, setidaknya ada beberapa konsep yang terkandung dalamnya yaitu: iman (keyakinan), Islam (kepatuhan) dan ihsan (keterpaduan antara hati dan pikiran dalm perbuatan yang baik) dan semua ini digerakkan melalui ilmu. Hakikat Ilmu dan klasifikasi ilmu yang dijabarkan oleh Syed Muhammad al-Attas ada dua macam pengetahuan yaitu: Pertama, merupakan santapan dan kehidupan jiwa itu yang diperoleh dan diberikan oleh Allah Swt. Pengetahuan yang diberikan oleh Allah ini meliputi al-Quran, Sunnah, Syari'ah, ilmu Laduni, dan hikmah yang berupa pengetahuan dan kearifan. Konsep pengetahuan dan kearifan sangat erat kaitannya dengan moralitas dan pendidikan. Sebab moralitas dan pendidikan merupakan sebuah unifikasi yang yang berasal dari bahasa Arab arif. Arif merupakan bentuk isim fa'il dari kata ma'rifah yang artinya mengetahui atau mengenal. ${ }^{26}$

Kearifan, menurut Al-Attas adalah pengetahuan yang diberikan Allah untuk memungkinkan pemilik pengetahuan untuk menerapkan dengan kebijaksanaan sedemikian rupa sehingga timbul keadilan. Sedangkan keadilan itu sendiri secara inheren mengandung pengertian pengetahuan. Jadi keadilan adalah keadaan eksistensial dari kearifan yang dinyatakan dalam sesuatu yang ditangkap pancaindra dan dapat dipahami akal budi serta dalam alam spiritual yang berkaitan dua jiwa manusia yaitu jiwa rasional (al-nafs al-nathiqah) dan jiwa hewani (al-nafs al-hayawaniyyah). Kedua, tujuan pengajaran yang operasionalistiik dan pragmatis yang cara perolehannya dapat dilakukan melalui pengalaman, pengamatan, dan penelitian. Pengetahuan ini mempunyai arti luas, deduktif dan berkaitan dengan objek-objek yang bernilai pragmatis.

Quthub al-Din al-Syirazi dan al-Farabi yang justru mendahulukan ilmu-ilmu rasional dan mengakhirkan ilmu-ilmu agama. Namun demikian, klasifikasi al-Gazhali yang secara garis besar membagi ilmu pengetahuan menjadi ilmu-ilmu syar'iah dan 
ilmu-ilmu ghair syari'ah. ${ }^{27}$ Sedangkan Ibnu Khaldum dengan nada yang hampir sama, mengklasifikasikan ilmu menjadi ilmu-ilmu naqliyah dan ilmu-ilmu aqliyah. Sebagai konsekuensi logis dari dua jenis pengetahuan diatas, maka dapat dikemukakan disini klasifikasi ilmu menurut al-Attas yang selanjutnya dijadikan sebagai kurikulum di universitas yang dipimpinnya, yaitu: Pertama, ilmu-ilmu agama yang meliputi al-Quran, al-Sunnah, Al-Syari'ah, teologi, metafisika Islam (Tasawuf), ilmu-ilmu linguistic seperti bahasa Arab, tata bahasa, leksikografi, dan kesusteraan. Kedua, ilmu-ilmu rasional, intelektual dan filosofis yang meliputi ilmu-ilmu kemanusiaan, alam, terapan, dan teknologi. 28

Dari gambaran yang telah disebut diatas oleh penulis, terlihat bahwa penggambaran intelektual Muhammad Naquib al attas merupan sebuah fenomena yang berangkat dari dunia metafisis menuju kepada dunia empiris, dan ini kebalikan dari penggambaran al-Ghazali. Perbedaan alur penggambaran ini sangat dipengaruhi oleh situasi dan kondisi yang dialami dan dihadapinya. bila Al-Attas berada dalam gemerlapan dunia modern yang penuh dengan kepalsuan, maka Al-Ghozali berada dalam dunia yang dalam kondisi politik yang tak menentu, dan timbul aliran-aliran yang sesat yang tidak sesui dengan Islam.

Pemikiran Al-Attas bila dilihat secara substantif termasuk katagori tradisional, jika dianalisis secara metodologis dia termasuk skripturalis, dan jika di tinjau secara historis maka tercakup dalam tipologi modernis. Akan tetapi menurut penulis, Al-Attas merupakan ilmuan yang termasuk tipologi reformis skriptualis. Meskipun pemikiran AlAttas mendasar pada teks-teks klasik, namun ia telah melakukan reaktualisasi dan reformasi agar sesuai dengan konteks era kontemporer (kekinian).

\section{Penutup}

Berdasarkan uraian diatas, dapat ditarik kesimpulan bahwa menurut Nuqaib, meski pengetahuan bersumber dari Tuhan bukan berarti pengetahuan hanya bisa dan harus digali dari wahyu. Usaha de-westernalisasi merupakan suatu proses kembali atau devolusi kepada makna-makna Islam yang orisonal. Dalam disiplin Ilmu dan

27 Osman Bakar, Hierarki Ilmu: Membangun Rangka Pikir Islamisasi Ilmu menurut al-Farabi, alGhazali, dan Quthb al-Din al-Syirazi, trans. by Munir, (Bandung: Mizan 1997), p. 247.

${ }^{28}$ Nizar, Filsafat Pendidikan Islam, p. 150. 
perbandingan agama, Al-Attas telah memberikan sumbangan yang berharga dengan menekankan perbedaan teologis yang fundamental antara agama Islam dan agamaagama lain dengan tetap mengakui kesamaan-kesamaan etika tertentu yang dengan toleransi dan keharmonian global dan antar komunikasi yang dapat ditegakkan.

Program Islamisasi ilmu pengetahuan kontemporer dan institusinya ini dipahami dan disebarkan dengan benar serta diterapkan dengan bijaksana, ia memiliki kemampuan yang unik dalam proses universalisasi prinsip-prinsip keagamaan dan etika-hukum serta dalam mempersatukan berbagai golongan umat manusia di sekitar mereka yang mampu menerobos rintangan-rintangan linguistik, sosial-ekonomi, gender, bahkan relijius. Karena prestasi historis (umat Islam) dan potensinya untuk berulang kembali, beberapa kelompok sekuralis sangat barhati-hati terhadap revolusi epistemologis yang kuat ini.

Untuk mencegah adanya dikotomi ilmu yang memisahkan secara total sisi religiuitas agama dalam pengembangan ilmu pengetahuan, perlu menjadi acuan bagi setiap lembaga pendidikan Islam yang ada saat ini agar tidak menghasilkan output yang justru tidak memiliki jiwa dan karakter yang islami. Naquib juga berusaha menjaga keseimbangan (equilibrium) dalam konsepnya antara aspek afektif, kognitif dan psikomotorik manusia sebagai potensinya sehingga mampu mengemban amanat Tuhan untuk menjadi khalifah fi al-ardh. Corak moral dan rilegius dalam mengemban tugasnya sebagai pencetak intelektual Muslim yang sadar akan realitas kehidupan guna mewujudkan insan kamil yang diidam-idamkan. Secara ilmiah Syed Naqib Al-Attas telah mengemukakan preposisi-preposisinya sehingga menjadi sebuah konsep pendidikan Islam yang jelas dan sistematis. 
Mawa'izh

Jurnal Dakwah dan Pengembangan Sosial Kemanusiaan

Vol. 10, no. 1 (2019), pp. 1-17.

DOI: https://doi.org/10.32923/maw.v10i1.781

\section{DAFTAR PUSTAKA}

Al-Attas, M. Syed Naquib, Islam dan Filsafat Sains, trans. by Saiful Muzani, Bandung: Mizan, 1995.

Bakar, Osman, Hierarki ilmu: Membangun Rangka Pikir Islamisasi Ilmu menurut alFarabi, al-Ghazali, dan Quthb al-Din al-Syirazi, trans. by Munir, Bandung: Mizan, 1997.

Barzinji, Jamil, Sejarah Islamisasi Ilmu Pengetahuan dalam Salam, ed2 \& 3. Malang: Pps UMM, 1998.

Daud Wan, Mohd Nor Wan, Filsafat dan Praktek Pendidikan Islam Syed M. Naquib alAttas. Bandung: Mizan, 2003.

Khodri, A .Soleh, Filsafat Islam Dari Klasik Hingga Kontemporer, Jakarta: Ar Ruzz Media, 2013.

Kurniawan, Syamsul \& Mahrus, Erwin, Jejak Pemikiran Tokoh Pendidikan Islam, Jakarta: Ar-Ruzz Media.

Muhaimin, Arah Baru Pengembangan Pendidikan Islam, Pemberdayaan, Pengembangan Kurikulum, Hingga Redifinisi Islamisasi Pengetahuan, Bandung: Nuansa, 2003.

Nizar, Samsul, Filsafat Pendidikan Islam Pendekatan Historis, teoritis dan Praktis, Jakarta: Ciputat Press, 2002.

Rahmat Abdul, Abdullah, Pemikiran Islam di Malaysia, Seajarah dan Aliran, Jakarta: Gema Insani Press, 1997. 